Ewa A. ŁUKASZYK

CY Advanced Studies / Cergy-Paris University

Cergy, France

ewa.a.lukaszyk@gmail.com

\title{
(POST)COLONIAL CHRONOPOLITICS AND MAPPING THE DEPTH OF \\ LOCAL TIME(S) IN GLOBAL LITERARY STUDIES: AN ITINERARY TO \\ GUINEA-BISSAU
}

Recommended Citation: Łukaszyk, Ewa A. "(Post)colonial Chronopolitics and Mapping the Depth of Local Time(s) in Global Literary Studies: an Itinerary to GuineaBissau”. Metacritic Journal for Comparative Studies and Theory 7.2 (2021). Doi: https://doi.org/10.24193/mjcst.2021.12.04

\begin{abstract}
This article is an attempt at deconstructing the chronopolitics inherent to the (post)colonial way of thinking about the world. As it is argued, what should replace it is a vision of multiple, overlying temporalities and forms of time awareness, reaching deeper than a literary history reduced to the cycle of colonisation - decolonisation postcolonial becoming, originating from just a single maritime event: the European exploration and conquest of the world. The essay brings forth a choice of interwoven examples illustrating the variability of local time depths, associated with a plurality of origins, narrations, forms of awareness and cultivation of cultural belonging. It shows the lack of coincidence between the dominant and non-dominant perceptions of the past in such places as the archipelagos of São Tomé and Príncipe, Maldives, the Gambia, Cape Verde and Guinea-Bissau. Their ways of living the global time, as well as embodying significant texts (rather than simply preserving them) stretch far beyond the frameworks created by competing colonial empires, such as the Portuguese or the British one.
\end{abstract}

Keywords: global literature, postcolonial chronopolitics, time awareness, oral $v s$ written literature, embodied text

\section{Deconstructing the presuppositions of colonised time}

The chronology of global literary studies is still dominated by the supposedly crucial 
importance of the colonial fact: first of all, the arrival of the Europeans, regarded as the auroral moment introducing the seeds of a new cultural reality, and then the sequence of decolonial emancipation, postcolonial becoming and literary flourishing. The persistent tendency to ignore local deep time and to privilege the shallow time established by colonisation and its consequences constitutes an ever-present shadow of European symbolic dominance. The chronopolitical attitude is adopted almost inadvertently by most scholars, even those who make, on the other hand, an enormous and honourable effort to give an account of the plurality of literary cultures around the world. Just to give an example of how the chronopolitical locus communis is widespread and taken for granted, one might quote a sentence from the work of Virginie Soula on New Caledonia, who writes just on the first page of her otherwise pertinent and ground-breaking study: "Certainly, the temporary depth of Caledonian writing has nothing comparable with that of European countries, of the Maghreb or even of the Caribbean, for the histories cannot be confounded. In the same fashion, it cannot be measured with the ancestral orality that is the foundation of Kanak culture". ${ }^{1}$ For a long time, it seemed impossible that such peoples as those remote Melanesians might be seen as full-right denizens of global time. It was only the arrival of the French sailors that connected them to such places - and such otherwise incommensurable temporalities - as that of Europe, the Maghreb and the Caribbean, creating for them common denominators like the concept of "Francophone literature".

The presupposition lying in the background of Soula's statement is that before the beginning of the colonial era, global time was split into various uncommunicated dimensions, and temporal depth was unstructured, filled with the magma of "ancestral orality", alien to any articulate time awareness. The literature in question, just like many other systems of expression around the world, thus seems condemned to live in the shallow time determined by the colonial fact and the dogma of separate histories that "cannot be confounded".

Quite to the contrary, as I claim, all local histories share the same objective time, a sequence of commensurable, intricately connected, interdependent presents, and a global history that interweaves them into an organic whole well beyond the direct influence of European explorers and colonisers. The cultures and the forms of literary

\footnotetext{
1 "Certes, la profondeur temporelle de l'écriture calédonienne n'a rien de comparable à celle des pays d'Europe, du Maghreb ou même de la Caraïbe car les histoires ne peuvent être confondues. De la même façon, elle ne peut être mesurée à l'oralité ancestrale qui fonde la culture kanak" (Soula 7). My translation.
} 
expression which they produce share time and convey meanings to one another, rather than staying closed in isolated space-time bubbles, awaiting European mediation. They are also able to do so independently of any colonial intermediaries. Denying their share in global becoming, across extensive time scales, is one of the remaining traces of the colonial device Divide et impera, still shaping the mental landscapes in which we live.

\section{Exploring the depth of local time awareness}

The shallow time scale imposed on global literary history, understood as the study of various forms of postcolonial writing across the world, may be summarised as a chronology of decolonisation, indicating just a few historical decades that encapsulate the whole process in several crudely defined steps: $1945-1955-1965$ and, finally, 1975, the date corresponding to the disintegration of the Portuguese colonial empire. The intellectual endeavour that counters this crippling vision of world literature as essentially born from those few decades of decolonial emancipation implies the development of a deeper awareness of global literary history as a network of temporalities, longues durées, culture-specific ways of experiencing and conceptualising time. The elements of this network form a whole that predates European expansion or works independently of colonial mediation. Such an endeavour permits to create a more encompassing, and at the same time more detailed view, in which the colonial/postcolonial facts are not necessarily pivotal. In this essay I will try to sketch some tentative fragments of such a vision.

At first glance, the comparison of various local cases seems to sustain the thesis of incommensurable histories that are connected and synchronised only upon the landing of the first European explorers. This is why Virginie Soula is ready to admit that, for the Kanaks, the participation in a global time of literary exchange started with the arrival of the French. Yet this perception may be maintained only as long as other maritime explorations are ignored. In any case, according to the dominant, Eurocentric presupposition, they are powerless to put into motion the clock of literary history, since oral expression, whatever forms it may acquire, remains immersed in an atemporal continuum, without structure or chronology. Other literacies are simply ignored or known only by such narrow circles of specialists that they have no significant impact inside the Western academia, nor do they contribute to the shaping of the dominant view of world literature. 
In fact, what remains to be done is a meticulous reconstruction of multiple layers and chains of maritime events. The case of two archipelagos situated on the opposite sides of the African continent might be illustrative of how intricate and complex those maritime histories actually are. The colonial cycle of São Tomé and Príncipe starts in the second half of the fifteenth century. Following their exploration in the 1470s, the Portuguese decided that the islands in the Gulf of Guinea would be an excellent place for a slave emporium connected with the African mainland. Later on, the colonial history of the islands, adapted for the intensive cultivation of coffee and cocoa beans, led to the advent of a local Creole middle class that inherited the archipelago after the collapse of the Portuguese colonial empire in 1975. The history of the Maldives may be told as quite an analogous narration, slightly transferred into the sixteenth century. It was only some decades later, in 1558, that the Portuguese established a trading post and a garrison administrated from their main outpost in Goa. Later on, the islands passed into other colonial hands, namely those of the British. This is why decolonisation came true a decade earlier than in São Tomé and Príncipe, in 1965. Both archipelagos seem to epitomise the shallow, yet almost perfectly synchronised time of the colonised world.

Nonetheless, a closer look at the Maldives leads to a veritable vertigo of time depth. In fact, the first settlement of the archipelago predates European colonisation by some 2,500 years. Its first clock of global history is synchronised with the Indian subcontinent, due to the conquest suffered by the archipelago almost at the dawn of History, during the Maurya period ( 600 to $180 \mathrm{BC}$ ). Also, the intellectual life of the archipelago cannot be reduced to unstructured orality without a chronology. Buddhist monasteries on the islands kept a detailed record of their history in copperplate books called lōmäfānu. Another strand of Maldivian literacy derives from the introduction of Islam into the archipelago. Certainly, the religious conversion added a new layer of written culture, as well as the awareness of belonging to a larger thought community with its own time depth and legacy. European scholars were well aware of these facts already by the end of the nineteenth century, due to the seminal work of Harry Charles Purvis Bell (1851-1937), a British civil servant and the first Commissioner of Archaeology in Ceylon, who published, in 1890, The Máldive Islands: Monograph on the History, Archaeology and Epigraphy (reprinted in 1940).

Arguably, this richness of writing and the awareness of local time depth must be seen as contrasting with the apparently much more modest and shallow time scale 
of São Tomé and Príncipe. After all, at the moment of its discovery by the Portuguese sailors João de Santarém and Pedro Escobar in 1470-1471, the archipelago was uninhabited. Nonetheless, also in this case the dominant colonial history obscures a plurality of origins and narrations of navigation that do not coincide with the Eurocentric perspective. The oldest literary patrimony of the islands is constituted by oral poems and narrations recording the origin of the Angolars - the Africans who survived the various catastrophes befalling slave trading ships. One of those narrations, recorded by Donald Burness, speaks of the Portuguese ship Misericórdia, sailing in 1532 from south Angola with a cargo of Umbundu slaves. As a consequence of their revolt, the Portuguese traders were put in a pinnace, while the main ship, adrift amidst the currents, crashed on the Sete Pedras, the dangerous rocky islets at the distance of $4.6 \mathrm{~km}$ off the south-east end of the Island of São Tomé (Burness 27). Other narrations vary, as far as the names of the ships and the exact circumstances are concerned; the place, Sete Pedras, remains the same, probably due not only to its value as a symbol of various shipwrecking scenarios, but also due to geographic and hydrological conditions making shipwrecks happen in the same spot over and over again. In any case, those maritime narrations create a consolidated vision of the origin of the Angolar community, which maintains a recognisable identity till the present day (according to various estimations, it forms a minority of several thousand up to 30,000 people). The Angolars live a modest life on the margins of the dominant Forro group, the Creoles that are at least partially the biological descendants of the Portuguese and the successors of their rule in the archipelago. Nonetheless, Angolar villages and towns, such as Santa Cruz (Anguéné) in the southern part of São Tomé, with their own "kings", remained autonomous till the second half of the nineteenth century, when they suffered pacification and were definitively submitted to the control of colonial administration. Be that as it may, it is fully legitimate to speak, in the case of the Angolars, about a continuity of time depth awareness that is independent in relation to the dominant, colonial and Creole narrations and that points to the African mainland as the root of their identity. Such a narration also inscribes them in a time horizon that is larger than colonial history and the circumstances of their coming to the archipelago.

\section{Mapping the affinities}

What appears as an open research task in the domain of global literary studies is the 
endeavour to build an encompassing vision that would put in the limelight the plurality of those underlying narrations that express a plurality of origins and ways of conceptualising local time depth. The result would be a new, more detailed and pluralistic chronology, as well as a more complete diagram of contacts and affinities with major sources of expression patterns and strands of intellectual tradition, independent in relation to the Western ones. The purpose of such a cognitive revolution is to abandon the vision that accentuates colonial history as the origin, the beginning or the major factor shaping time perspectives of the places that are still perceived as the margins of global history, while in reality they have always been fullright participants in the process of global becoming.

A common misunderstanding related to those alleged marginal areas is to associate - and thus to celebrate - the facts derived from colonial circumstances as the auroral moments of literary creation. Such a misunderstanding may be observed in the celebration of Phillis Wheatley (1753-1784) as "the first poetess of the Gambia". Born on the western shore of Africa, she was sold into slavery at the age of eight and brought to the United States. She learned how to write as a servant of a family that lived in Boston. This is how she found apparently propitious conditions to produce Poems on Various Subjects, Religious and Moral by Phillis Wheatley, Negro Servant to Mr. John Wheatley, of Boston, in New England, first published in 1773 and reedited by John C. Shields in 1988.

Certainly, as a young Afro-American female triumphant in a patriarchal society, Phillis Wheatley may remain an inspiring figure for many people today. Nonetheless, the focus on such a literary event as her individual - and certainly exceptional - access to literacy and literary prestige (in fact, merely a picturesque exception that served to legitimise the oppressive system in which she was immersed) relegates to the shadow the temporal depth of Gambian culture, for which the eighteenth century was in fact one of the turning points, but not thanks to the emergence of the English-language poetry written by a charming servant, but rather to the development of Sufi brotherhoods that established a framework for a specific literacy and tradition of learning.

The intellectual history of Western Africa, a rather obscure and unexplored research field, is currently the object of extensive, extremely detailed studies, such as, just to provide an illustrative example, the recent monograph of one such brotherhood published by Zachary Valentine Wright. In Realizing Islam. The Tijaniyya in North 
Africa and the Eighteenth-Century Muslim World, among a crowd of Sufi scholars, saints and text producers spanning the Sahel and North Africa from Mauritania to Morocco and Sudan, there appear also Senegambian figures, such as Mālik Sy and 'Abdallāh Niasse (Wright 216). In the nineteenth and early twentieth centuries, those Sufi personages contributed to maintain the cohesion of a cultural tradition and a stable sense of belonging in West African populations, leading them throughout the colonial period. Nonetheless, just as the English-language poetry of Phillis Wheatley seems easily accessible to everyone, specialised knowledge about West-African Sufis remains the appanage of a narrow and extremely exclusive circle of specialists.

Meanwhile, such strands of tradition as Sufism, although arguably not corresponding strictly to the Western definition of either intellectual or literary movements, undoubtedly connect vast areas of the world and contribute to the creation of a consistent translocal literary tradition, such as that of the prodigious, fantastic biographies of Sufi holy heroes (pīrs). They cover an area that goes from Senegal and the Gambia in the West to Bengal in the East. Through both its geographic extent and its awareness of time depth, Sufi literature might easily outcompete most of the literary phenomena brought into existence by colonial processes. Nonetheless, the exploration of this material in terms of its contribution to global literary studies, in such disciplines as global literary history or the global theory of genres is still incipient. The first steps, nonetheless, have been taken. Just to give an example exploring the literary patrimony on the opposite end of the Sufi world, the recent work of Tony Steward, Witness to Marvels. Sufism and Literary Imagination, might be cited. It strives not only to describe the peculiarity of the genre of kathā (a long narration, often counting hundreds of pages, developing, as a rule, a religious topic), but also to connect it with the Western schools of reflection on literary categories, namely with Northrop Frye's reflections on the Bible and Linda Hutcheon's research on parody that may also be applied, as Steward claims, to the fabulous narrations of eastern Bengal (Steward 190). Nonetheless, such works are still an exception and a novelty in the general landscape of literary studies.

\section{Time depth beyond the dualism of oral and written tradition}

Sufi literature has the advantage of being a written patrimony, a fact that provides it with a certain value of palpability and stability across time. Nonetheless, the channels 
of communication privileged in this particular cultural and intellectual formation constantly oscillate between written word and orality, the sacralisation of writing that issued from the Qur'anic tradition and the accentuation of the direct, personalised, embodied transmission from master to disciple. ${ }^{2}$ Such a duality, intensely present in West African culture, forces the Western scholar to rethink the status of orality and its peculiar role in shaping the awareness of temporal depth. Orality often used to be dismissed as something essentially a-temporal, something less reliable in establishing an awareness of time depth and a sense of chronology. It may not be exactly so in West African perception. A peculiar efficiency of orality becomes very obvious in the patrimony of the Mandinga world, transmitted by a specialised intellectual class that the early French researchers qualified as griots (the local denomination of the members of this class is djeli). Living in the horizon of not only colonial, but also Islamic literacy, the griots have a full awareness of both the potential and the shortcomings of writing.

In 1960, the Senegalese historian Djibril Tamsir Niane resolved to produce a printed version of the orally transmitted narration of Djeli Mamadou Kouyaté (a Guinean griot who died in 1991 in Burkina Faso), concerning the deeds of Soundjata Keita, the first emperor of Mali, crowned under the name Mari Diata I (1190-1255). 3 Not only did the narration correspond to a historical figure, but Mamadou Kouyaté also claimed to represent a sort of embodied memory of this history as a biological descendant of Balla Fasséké, the griot who actually accompanied Soundjata Keïta and preserved the exact account of his deeds not only as a direct testimony of the events, but also so to speak as a living warrant, embodying the narration and stamping it indelibly on the personal identity of his descendants. The factual exactitude of the narration may be easily brough into question. It contains many elements that appear to have some sort of symbolic rather than literal significance, such as the birth of the future ruler as a cripple son of a cripple mother (a hunchback "buffalo woman"). Also,

\footnotetext{
${ }^{2}$ It is important to notice that the Qur' an is a text that epitomises the duality of orality and literacy due to the high appreciation of the persons who learn it by heart. During my travels to Gambia some years ago, I was surprised by the number of small Qur' an memorisation schools being advertised in the streets of Banjul. The traditional art of Qur'anic recitation has been in decline everywhere across the Islamic world after the advent of the audio cassettes providing easy access to the engravings of the most appreciated imams. Yet memorisation, as a specific way of "incarnating" the holy text or searching for mystical oneness with it seems to have a special weight in the cultural landscape of West Africa.

${ }^{3}$ An analogous narration was printed again in 1988, in an ampler version elaborated by the ethnologist Youssouf Tata Cissé from Mali, under the title La Grande Geste du Mali. It was based on the oral tradition transmitted by another griot, Wâ Kamissoko (1925-1976).
} 
the kinship between the twentieth-century griot and his thirteenth-century alleged forefather seems to be a fictionalised element, part of an "invented tradition", rather than something that should be taken as literal truth. Nonetheless, it is imperative to understand the importance of embodiment as a specific way of transmission, creating the tension between temporal depth and the strictest presentness of the speaking person during the face-to-face encounter in which the presentation and the "presentification" of the text take place.

It is equally interesting to see the arguments brought forth by Kouyaté to dismiss the exclusivity of literacy and written tradition and to stress the superiority of the embodied text, represented by a living person, as a means of building an intense, emotional engagement with the past: "Other peoples use writing to fix the past; but this invention killed memory among them; they don't feel the past any longer, because writing does not possess the warmth of the human voice (...). How feeble is the knowledge that is fixed in silent books". 4 As we put aside the question of factual reliability, the efficiency of oral transmission as a way of building the awareness of deep time is obvious. It is precisely through such an embodied, personalised approach in which a living voice grants the connection with the past that the cultural inscription in a vast temporal horizon is most intensely experienced.

\title{
Delving into the abundance and scarcity of time
}

On the other hand, the shallowness of postcolonial time may be sorely felt. A poem by Tony Tcheka, from Guinea-Bissau, may serve as testimony to a culture in which the link with temporal depth has been severed:

\author{
Being sick, I decline the invitation \\ to the great feast of liberty \\ I stay in my time \\ in my space \\ in my village \\ where the feast \\ is crying
}

\footnotetext{
4 "D'autres peuples se servent de l'écriture pour fixer le passé; mais cette invention a tué la mémoire chez eux; ils ne sentent plus le passé car l'écriture n'a pas la chaleur de la voix humaine (...). Quelle piètre connaissance que la connaissance qui est figée dans les livres muets" (Niane 78-79). My translation.
} 
is sickness

is a child dying 5

The independence of the former Portuguese Guinea, presented as a declined invitation to join the dynamic flux of history, in which such values as democracy, liberty, or progress might be realised, is seen as a dysphoric event. The poet - and the community he represents - remain in "his time", epitomised by the traditional village (tabanca). This particular space-time inscription lacks both: there is no link to the enlivening richness of African culture; on the other hand, the tabanca's present is marked by problems that cannot be solved precisely because it stays on the margins of global time. Such a problem as the measles epidemic decimating the Guinean children throughout the first postcolonial decades, which could only be eradicated with modern vaccination, epitomises the stakes of the declined participation in the flux of modernity. In fact, various time dimensions have been severed concomitantly: the flux of tradition has been stopped without granting the possibility of participation in the "great feast" of postcolonial liberty. Time as a harmonious connection between the past, the present, and the future is conveyed as negation. A static, suspended temporality of stagnation ensues instead.

It is striking that the poetry that may be found today in the archipelago of Cape Verde, just a few hundred nautical miles from the shores and archipelagos of GuineaBissau, proudly proclaims its inscription in global literature and its deep time, expressed as a deliberately constructed maze of intertextual connections, allusions, links of intellectual kinship. In a parody of epic diction evoking the great sixteenthcentury maritime epic of the Portuguese, The Lusiads by Luís Vaz de Camões, Filinto Elísio proclaims his heroic conquest of world literature:

Like the gods on the Olympus, in a quarrel,

I muse on Luís Vaz, on the destiny of Gama,

they say the death of Omerus, in Walcott

in nothing else than the Odyssey, the one of Ulysses.

(...)

To love Penelope and to reach one's target

\footnotetext{
5 "Enfermo declino o convite / para a grande festa da liberdade / Estou no meu tempo / no meu espaço / na minha tabanca / onde festa / é choro / é doença / é criança morrendo" (Tcheka, Noites 69). My translation.
} 
just like the arrow in Soyinka, the lion's descendant,

Sidi, all that was nothing but wine in Omar Khayyam... ${ }^{6}$

The poem may eventually be read as a gendered proclamation of new male heroism, that of literary glory rather than arms, expressed in a daring re-inscription in a topos taken from European classical literature. Deploying his shimmering network of intertextual references, Filinto Elísio reinvents the inscription of the literature of Cape Verde in the deep time of global literature, establishing not only the connection with Greek and Roman mythology, as his predecessors from the generation of the review Claridade already attempted in the first half of the twentieth century, but also seeking more diversified relations and affinities, reaching further and deeper in time, as he does while evoking the figure of the Persian poet Omar Khayyam (1048 - 1123). Postcolonial time is included, mapped, but it is so to speak placed in parenthesis, as if neutralised by the temporal and geographic vastness of the entire intertextual network.

Certainly, in Filinto Elísio one may read a happy vision of a global inscription of the lonely volcanic archipelago situated between 600 and 850 kilometres off the westernmost point of continental Africa. This new heroic vision, making, without any sense of bashfulness, unrestrained use of the existing literary codifications of the male condition, is based upon a deep time awareness. On the other hand, in the shallow time of Guinea-Bissau, the new global inscription of the African male takes quite an unheroic turn under the pen of Tony Tcheka:

\author{
the matchus of incapacity \\ of doing nothing \\ matchus allergic to difference \\ eager to see blood \\ and get some white powder \\ give me taco - patacon, kumbu, money \\ and the time goes by \\ with resignation \\ we dissolve into a sulphuric mud \\ we lose the haven
}

\footnotetext{
6 "Os deuses, em dissídio, como por Olimpo, / cogito de Luís Vaz, à sorte de Gama, diziam / que à morte de Omerus, no canto de Walcott, / era, em tudo, senão Odisseia, a de Ulisses. / (...) / Amar Penélope, doze machados vencer, / tal flecha em Soyinka, da prole do leão, / ao que Sidi, era vinho em Omar Khayyam..." (Elísio 53). My translation.
} 
and we are without an anchor! 7

Local perceptions of global time could not be more dissimilar. On the one hand, in Filinto Elísio, inscription in the global literary tradition provides a sense of abundance, of time flowing from multiple pasts into a creative, unabashed present, confident of a heroic future. With the evocation of other postcolonial literatures, such as Derek Walcott's Saint Lucia, the insular time of Cape Verde communicates with other insular temporalities. The maritime narration of the Portuguese, their glorious circumnavigation of Africa, and the discovery of the road to India are integrated as one origin of many. On the other hand, in Tony Tcheka, time without depth is translated into exclusion, marginalisation, and the inglorious and unheroic isolation of the male - designed as matchu, a Creole word introduced into the Portuguese matrix of the poem to indicate the peculiar status of this individual, male sui generis, as if standing on the margins of a proper gender identity. Such places as the Archipelago of Bijagós, the western part of Guinea-Bissau, found their global inscription as part of the international network of drug smuggling. No wonder that globalisation, seen from this local perspective, appears as a degrading process, a final dissolution of individuals, communities, and identities. The poetry of Tony Tcheka searches for the expression of localised experience, without any investment in intertextual networks. It connotes the absence of meaningful tradition, the broken chain of cultural transmission. This is why the Guinean time evoked in the poem "goes by", leaving no legacy behind.

\section{Final remarks}

An often-repeated scholarly narration concerning the emergence of Lusophone African literatures accentuates the importance of a single institution, Casa dos Estudantes do Império in Lisbon (1944-1965). Created by the Salazarian regime in order to control the students coming from various parts of the Portuguese colonial empire, it contributed, quite to the contrary, to the dissemination of ideas concerning the decolonising process, as well as paradigms of literary expression that should accompany it. Those corrosive ideas were essentially shared between the left-wing Portuguese and African intellectuals. This "centralised" vision of the birth of

\footnotetext{
7 "Os matchus da incapacidade / do nada fazer / matchus alérgicos à diferença / afoitos ao sangue / ao pó branco / dá taco - patacon, kumbu, money / E o tempo passa / nós resignados / desfazemo-nos no lodo sulfúrico / perdemos o porto / e ficamos sem âncora!” (Tcheka, Desesperança 22-23). My translation.
} 
Lusophone literatures necessarily presupposes their synchronisation with metropolitan time. The forms of postcolonial literary expression were supposedly derived from the creative logic of Portuguese literature, and constituted a continuation of the peculiar forms of neorealism in Portuguese poetry and prose. It was in these terms that the early researchers of African "literatures of Portuguese expression" (literaturas de expressão portuguesa) tried to conceptualise them, paying little attention to local idiosyncrasies and striving for conclusions that would put in the limelight the unity of the literary system, in spite of the fragmentation of the colonial empire. Lusophone literature was to redeem the fiasco of the colonial project, providing the Portuguese with a sort of post hoc justification.

Certainly, this vision does not offer any explanation for the obvious disparity between local chronologies. The modern literary movement in Cape Verde, with the already mentioned review Claridade, was in full bloom already in the 1930s. The emergence of a fully articulated system of written literary expression in Guinea-Bissau happened as late as the 1990s. What is even more important, the disparity between local time perceptions in those newly born Lusophone literatures is hard to explain as long as this unitary decolonial narration is maintained.

The literature of countries like Guinea-Bissau cannot be read uniquely as a result of colonial history, shared with Cape Verde to such a degree that an early postcolonial political project intended to join both territories in a single state. Cape Verde has a relatively strong Creole middle class, in many ways analogous to that of São Tomé, characterised above. In both archipelagos, these dominant social groups seek to increase their symbolic weight through literary prestige. On the other hand, the underlying cultural reality of Guinea-Bissau is a fractal mosaic of ethnic groups, many of them survivors of consecutive genocides committed in the shadow or on the margins of the Portuguese colonial presence. Their evanescent legacies are made of residual traditions squeezed between the colonising forces and other aggressive histories, such as those of African providers working in the benefit of the slave trade controlled by the Portuguese, but not exclusively. The second half of the nineteenth century brought the impact of jihadist movements, such as that of the theocratic Futa Djallon Confederacy. More recently, further violence has been committed by local tribesmen at the instigation of the colonisers. Such was the case of the bloodcurdling rule of the Wolof warlord Abdul Indjai (sometimes spelled Ndjai). Such an improbable ally of the colonial rule became useful when, in the aftermath of the Berlin Conference 
(1884-1885), Portugal launched a series of "pacification" campaigns from 1891 to 1910, especially in the "rebellious" region of Oio (Mendy, Lobban 236-37). The cycle of domestic conflicts in Guinea-Bissau did not end with decolonisation, but found its continuation in the civil war fought in 1998-1999 and a streak of military coups that continues almost to the present day.

In Guinea-Bissau, the colonial presence was only one of the sources of violence; no wonder that decolonisation and the beginning of the postcolonial era brought to light further layers of dire experience that strives for its own ways of expression despite the condition that might be defined as a scarcity of tradition. This particularly bloody history that might be summarised as a grinding mill of colonial and non-colonial aggression is in large measure responsible for the broken chains of local cultural transmission. Plural histories that foster an increased deep time awareness in some regions may also become a disempowering factor in others. The result is the perception of a narrowness, a shallowness or an absence of time, as well as the longing for its emergence, an advent of a new temporality including a future, not just a sore past and a swampy, stagnating present.

Acknowledgment: This work received funding by the CY Initiative of Excellence (grant "Investissements d'Avenir" ANR-16 IDEX-0008); it was developed during Ewa Łukaszyk's stay at the CY Advanced Studies whose support is gratefully acknowledged.

\section{References:}

Bell, H. C. P. The Máldive Islands: Monograph on the History, Archaeology and Epigraphy. Ceylon Government Press, 1940.

Burness, Donald. Ossobó. Ensaios sobre a Literatura de Sao Tome e Principe. Câmara Municipal de Lagos, 2007.

Cissé, Youssouf Tata, Kamissoko, Wâ. La grande geste du Mali. Des origines à la fondation de l'Empire. Karthala, 2007.

Elísio, Filinto. Zen Limites. Rosa de Porcelana, 2016.

Mendy, Peter Karibe, Lobban, Richard A. Historical Dictionary of the Republic of Guinea-Bissau. The Scarecrow Press, 2013.

Niane, D. T. Soundjata, ou l'épopée mandingue. Éditions Présence Africaine, 1960.

Soula, Virginie. Histoire littéraire de la Nouvelle-Calédonie (1853-2003). Karthala, 2014. 
Tcheka, Tony. Noites de insónia na terra adormecida. Instituto Nacional de Estudos e Pesquisa, 1996.

Tcheka, Tony. Desesperança no chão de medo e dor. Edições Corubal, 2015.

Shields, John C. (ed.). The Collected Works of Phillis Wheatley. Oxford University Press, 1988.

Steward, Tony. Witness to Marvels. Sufism and Literary Imagination. University of California Press, 2019.

Wright, Zachary Valentine. Realizing Islam. The Tijaniyya in North Africa and the Eighteenth-Century Muslim World. The University of North Carolina Press, 2020. 